\title{
USE OF CELLULASES TO PREDICT IN VIVO DIGESTIBLE ORGANIC MATTER (D VALUE) IN PASTURE SILAGES
}

\author{
Claudia Barchiesi-Ferrari' ${ }^{1}$, Daniel Alomar ${ }^{2 *}$, and Horacio Miranda ${ }^{1}$
}

\begin{abstract}
In pasture-based dairy herds where silage is a widely adopted supplement, optimized feeding requires reliable estimations of nutritional quality of this conserved forage. Metabolizable energy, an important nutritional fraction, can be predicted from digestibility-related traits, such as the digestible organic matter contained in the dry matter (D-value). The aim of the present study was to evaluate the prediction of D-value and dry matter digestibility (DMD) of grass silages made from four different pastures and maturity stages, using the pepsin-cellulase method. Fungal cellulase was used, applying different enzyme concentrations, incubation times and types of final wash. The silages were prepared from permanent pasture (Dactylis glomerata L., Lolium perenne L., Bromus catharticus Vahl var. catharticus, Trifolium repens L. and Holcus lanatus L.), rotation pasture (Lolium multiflorum Lam. cv. Tama), oats (Avena sativa L.), and mixed pasture (L.perenne-T. repens). These were harvested at three different physiological stages (vegetative, ear emergence and dough grain). The treatment using an incubation time of $24 \mathrm{~h}$, a cellulase concentration of $6.25 \mathrm{~g} \mathrm{~L}^{-1}$ and final wash with water (Treatment 3) presented the best prediction capacity of the in vivo $\mathrm{D}$-value $\left(\mathrm{R}^{2}=0.78\right)$ and in vivo $\mathrm{DMD}\left(\mathrm{R}^{2}=0.71\right)$. In vivo $\mathrm{D}$-value prediction improved $\left(\mathrm{R}^{2}=0.8\right)$ when a chemical determination (crude fibre, gross energy, neutral detergent fibre, total ash or acid detergent fibre) was included in addition (multiple regression) to D-value obtained with cellulases (Treatment 3). Results of DMD obtained with cellulases show good precision, but underestimate in vivo values, and are closer to those obtained with ruminal fluid. Suitable equations could be used to improve accuracy.
\end{abstract}

Key words: pasture silage, in vitro, digestibility of dry matter, Trichoderma viride.

$\mathrm{P}$ asture-based dairy systems require conserved forage to supplement cows during periods when grass growth rate is low. Pasture silage is frequently used as an important component of the winter diet, particularly in humid, temperate zones. In these management conditions, the yield of the herd depends heavily on the quality of the silage, in terms of both its digestibility and fermentation characteristics (Huhtanen et al., 2005).

Systems for the evaluation and formulation of rations need precise, reliable estimates of the digestible or metabolizable energy content of the forage, which are in many cases predicted from digestibility values. Various chemical and in vitro methods have been developed to predict in vivo digestibility of the forage. The use of regressions to estimate the in vivo dry matter digestibility

${ }^{1}$ Universidad de La Frontera, Facultad de Ciencias Agropecuarias y Forestales, Av. Francisco Salazar 01145, Temuco, Chile.

${ }^{2}$ Universidad Austral de Chile, Facultad de Ciencias Agrarias, Casilla 567, Valdivia, Chile. "Corresponding author (dalomar@uach.cl). Received: 23 June 2010.

Accepted: 16 December 2010.

(DMD), organic matter digestibility (OMD) and D value in silage, either based on the cell wall content (neutral detergent fibre or NDF) or on cell wall related fractions, such as crude fibre (CF), acid detergent fibre (ADF), modified ADF or lignin; or even on the content of crude protein $(\mathrm{CP})$, in general presents poor performance (Nousiainen et al., 2003). The in vitro techniques based on ruminal fluid or commercial enzymes allow more accurate predictions to be obtained, with better repeatability (Jones and Theodorou, 2000). The use of ruminal fluid is widespread and is used to predict the digestibility of a broad range of forages. However, it presents a series of disadvantages such as a) possible alteration in the activity of the ruminal fluid; b) donor animals must be kept on a standard feed regimen to minimize the variability of the inoculum; c) technical difficulties (maintenance of anaerobic conditions, leakage problems); d) it requires to maintain fistulated animals (Jones and Theodorou, 2000). Also, Di Marco et al. (2009) pointed out that in vitro results can be affected by several additional factors, such as grinding size, distribution of particle size in the 
sample and concentration of inoculum. It is also worth considering that in vivo data cannot be disregarded in the search for a reliably accurate and precise digestibility approach, which still remains to be identified (Robinson et al., 2004).

A complementary approach is the use of near infrared reflectance spectroscopy (NIRS) which has been widely established as a fast, multiple, precise and accurate technique to predict composition and digestibility traits. However, to obtain robust calibrations, a large number of samples with their spectral data is required, covering a wide range of variation in digestibility and reliable reference values to develop prediction equations with an acceptable degree of certainty (Alomar and Fuchslocher, 1998; Rinne et al., 2006; Ibáñez and Alomar, 2008).

Fungal cellulases have been used to break down cell walls, imitating ruminal degradation, and variations of this enzymatic method have been studied to evaluate forage digestibility (Jones and Hayward, 1975; Dowman and Collins, 1982; Nousiainen et al., 2003; Huhtanen et al., 2005). It has also been claimed that the use of commercial enzymes allows greater precision (Jones and Theodorou, 2000) with less digestion time than the in vitro method with ruminal fluid.

As the use of cellulases appears as a good alternative to evaluate forage quality and a method that could offer a high correlation with in vivo results, the objective of this work was to study variations of the cellulase in vitro technique, in order to select a treatment that, alone or combined with some chemical determinations, could be used to improve the prediction of the in vivo digestibility of pasture silages.

\section{MATERIALS AND METHODS}

Silages from four types of pastures in three phenological stages were evaluated. The pastures were: a) Permanent pasture (Dactylis glomerata L., Lolium perenne L., Bromus catharticus Vahl var. catharticus, Trifolium repens L. and Holcus lanatus L.); b) short term rotational pasture (Lolium multiflorum Lam. cv. Tama); c) oats (Avena sativa L.) and d) mixed pasture (L. perenne-T. repens). Each pasture was harvested in three phenological phases (of the dominant grass species): vegetative, early heading and soft dough grain. Stack silos were filled in duplicate for each pasture type and phenological stage, with $c a .3000 \mathrm{~kg}$ fresh forage each and subsequently were sealed with polyethylene. Digestibility trials took place after a fermentation period in excess of 3 month.

\section{In vivo and in vitro (rumen fluid) digestibility}

The in vivo digestibility of the silages was determined with four Friesian bull calves (175 kg average live weight). A 10-d period of adaptation to the silages was followed by $6 \mathrm{~d}$ with ad libitum consumption of silage to determine voluntary intake. Subsequently, calves were transferred to metabolic rates, and offered $70 \%$ of the previously determined consumption. In the collection stages, of $6 \mathrm{~d}$ each, composite samples of silage, faeces and urine were taken and frozen at $-20{ }^{\circ} \mathrm{C}$ until the moment of analysis.

The in vitro digestibility of each silage was determined with rumen fluid and the enzymatic technique and, from these, the D value, DMD and OMD were calculated. The rumen fluid technique was applied according to Tilley and Terry (1963).

\section{Enzymatic digestibility}

The pepsin-cellulase method described by Jones and Hayward (1975) was used, considering certain modifications in the cellulase concentration $(0.75 ; 1.0$ or $6.25 \mathrm{~g} \mathrm{~L}^{-1}$ solution), incubation time ( 24 or $48 \mathrm{~h}$ ) and type of final wash (hot distilled water or acetone) giving a total of 12 treatments: $\mathrm{t} 1: 24 \mathrm{~h}$, water, $0.75 \mathrm{~g} \mathrm{~L}^{-1} ; \mathrm{t} 2: 24 \mathrm{~h}$, water, $1.0 \mathrm{~g} \mathrm{~L}^{-1} ; \mathrm{t} 3: 24 \mathrm{~h}$, water, $6.25 \mathrm{~g} \mathrm{~L}^{-1} ; \mathrm{t} 4: 24 \mathrm{~h}$, acetone, 0.75 $\mathrm{g} \mathrm{L}^{-1}$; t5: $24 \mathrm{~h}$, acetone, $1.0 \mathrm{~g} \mathrm{~L}^{-1}$; t6: $24 \mathrm{~h}$, acetone, 6.25 $\mathrm{g} \mathrm{L}^{-1}$; t7: $48 \mathrm{~h}$, water, $0.75 \mathrm{~g} \mathrm{~L}^{-1}$; t8: $48 \mathrm{~h}$, water, $1.0 \mathrm{~g} \mathrm{~L}^{-1}$; t9: $48 \mathrm{~h}$, water, $6.25 \mathrm{~g} \mathrm{~L}^{-1}$; t10: $48 \mathrm{~h}$, acetone, $0.75 \mathrm{~g} \mathrm{~L}^{-1}$; $\mathrm{t} 11: 48 \mathrm{~h}$, acetone, $1.0 \mathrm{~g} \mathrm{~L}^{-1}$; t12: $48 \mathrm{~h}$, acetone, $6.25 \mathrm{~g} \mathrm{~L}^{-1}$.

Cellulase from Trichoderma viride was used (Onozuka R-10, Yakult Pharmaceutical, Japan, activity $11.7 \mathrm{U} \mathrm{g}^{-1}$ ). The enzymatic digestion was carried out by adding 500 mg of sample (oven dried at $60{ }^{\circ} \mathrm{C}$ and ground to pass a $1 \mathrm{~mm}$ screen) to $60 \mathrm{~mL}$ test-tubes with twist caps. A 50 mL solution of 2\% pepsin (2000 FIP-U g ${ }^{-1}$; Merck 7190, Darmstadt, Germany) with $0.1 \mathrm{~N}$ hydrochloric acid was added and the tubes were shaken. Thereafter, the tubes were incubated at $39^{\circ} \mathrm{C}$ for $24 \mathrm{~h}$, shaking every $6 \mathrm{~h}$. After incubation, samples were vacuum filtered (Whatman 41 filter paper) and the residue was washed with hot distilled water. The residue in the paper was then transferred back to the respective test-tube by washing with a syringe with $50 \mathrm{~mL}$ of buffer cellulase solution, prepared the day before and taking special care not to leave any visible particle of the residue in the paper. Each tube was shaken and incubated at $39{ }^{\circ} \mathrm{C}$ for 24 or $48 \mathrm{~h}$, in accordance with the respective enzymatic treatment, shaking four times a day. After the incubation was finished, the contents of the tubes were filtered through pre-weighed sintered glass crucibles (Schott Duran, porosity \# 1, Mainz, Germany) and washed with hot distilled water or acetone, according to treatment. Crucibles with residues were dried at $105^{\circ} \mathrm{C}$ for $12 \mathrm{~h}$ and weighed to obtain the content of indigestible DM. Twelve silages samples were used in each treatment. Thereafter, the crucibles were ashed at $500{ }^{\circ} \mathrm{C}$ for $5 \mathrm{~h}$ in an electric muffle furnace, cooled in desiccators to room temperature and reweighed to obtain the indigestible 
organic matter. A blank was used with each batch of analysis. With these values, DMD, OMD and D value, were calculated.

The enzymatic in vitro digestibility was calculated as follows:

$\mathrm{DMD}=(\mathrm{DW}-\mathrm{FW}) / \mathrm{DW} * 100$

$\mathrm{D}$ value $=($ initial $\mathrm{OM}-$ final $\mathrm{OM}) /$ initial $\mathrm{DM} * 100$

$\mathrm{OMD}=(\mathrm{OM}-(\mathrm{FW}-\mathrm{TRA})-\mathrm{B}) / \mathrm{OM} * 100$

where: $\mathrm{DMD}=$ digestibility of dry matter $(\%)$; DW = weight of dry sample $(\mathrm{g}) ; \mathrm{FW}=$ final residual weight post incubation $\left(105^{\circ} \mathrm{C}\right)(\mathrm{g})$; D value $=$ digestible organic matter contained in the dry matter $(\%)$; OM = organic matter $(\mathrm{g}) ; \mathrm{DM}=$ dry matter $(\mathrm{g})$; OMD = digestibility of the organic matter $(\%)$; TRA = total residual ash $(\mathrm{g}) ; \mathrm{B}=$ blank.

\section{Chemical analysis}

The following fractions were determined in the silages: DM (AOAC, 1996, method 930.15), total ash (TA) (AOAC, 1996, method 942.05), $\mathrm{N}$ by Micro Kjeldhal (AOAC, 1996, method 984.13), crude fibre (CF) and acid detergent fibre (ADF), according to AOAC (1996) (methods 978.10 and 973.18 respectively), neutral detergent fibre (NDF) (Van Soest et al., 1978). Silage $\mathrm{pH}$ was obtained by potentiometric reading of the extract. Ammonia N was determined by titration on the Kjeldahl distillate (Bateman, 1970). Gross energy (GE) was obtained with a bomb calorimeter (Parr adiabatic calorimeter; Parr Instruments, Moline, Illinois, USA). Metabolizable energy (ME) was estimated from the D value, according to a local regression (Garrido and Mann, 1981).

\section{Statistical analysis}

Regression analysis was performed to evaluate the ability of the different cellulase treatments to predict the in vivo $\mathrm{D}$ value and in vivo DMD (dependent variable), with D value and DMD obtained with cellulases, as the respective independent variable. To the same end, multiple regressions were adjusted, adding NDF, ADF, $\mathrm{CF}$, GE or TA, as a second independent variable to the enzymatic results.

Comparisons were made among the equations, in order to select the best enzymatic treatments, based on the percentage of the variance of the dependent variable explained by the regression $\left(\mathrm{R}^{2}\right)$. Furthermore, an estimation error (or residual standard deviation) was also used as a criterion, corresponding to the root mean square of the residues (Steel and Torrie, 1988; Cody and Smith, 1991). The statistical analyses were done using the JMP computer programme, Version 8 (SAS Institute, 2009).

\section{RESULTS AND DISCUSSION}

\section{Composition of the silages}

A great degree of variation was observed in the composition of the silages, in terms of their chemical and chemicalbiological traits (Table 1), which probably results from the different pastures included and the phenological stages at which they were harvested. Although increasing maturity of the harvested forage not always resulted in an increase in fibre related fractions in the respective silage, this diversity is desirable when regression analysis is involved, such in this case, to relate the performance of the enzyme method as a predictor of in vivo digestibility.

\section{Prediction of in vivo digestibility traits from the enzymatic results}

Tables 2 and 3 present the equations for the prediction of the in vivo D value and DMD respectively, using different treatments with cellulases. It may be observed that Treatment 3 showed the greatest capacity to predict these digestibility traits, explaining 0.78 and 0.71 of the variance of $\mathrm{D}$ value and DMD respectively, and with a lower estimation error (4.27 and 3.38\% respectively). The coefficient of variation obtained with Treatment 3 was lower than the other treatments, both for D value $(6.57 \%)$ and DMD (5.37\%). According to these results, Treatment 3 would be the best (Figure 1). Although the estimation error increases slightly (to $3.57 \%$ ) when the wash is done with acetone (Treatment 6 ) this type of washing should be considered since it allows better chlorophyll extraction. On average, the treatments using $6.25 \mathrm{~g}$ cellulase $\mathrm{L}^{-1}$ were 5.5 and $13.9 \%$ better at estimating in vivo DMD than the treatments which included 1.0 and $0.75 \mathrm{~g}$ cellulase $\mathrm{L}^{-1}$, respectively. It is noteworthy that when incubating for $24 \mathrm{~h}$ (Treatment 3) results are slightly better than with a longer incubation (Treatment 9) with cellulase.

Dowman and Collins (1982), analyzing 16 grass silages by the in vivo method, found that the $\mathrm{D}$ value fluctuated between 64 and $78 \%$, while when cellulases were used; the values fluctuated between 50 and $68 \%$, roughly ten percentage points below the in vivo method. Our results also agree with the proposal of Rinne et al. (2006), who indicate that the regression coefficients for the relationship between OMD cellulases (and also between OMD ruminal fluid) and in vivo values are $10 \%$ lower, suggesting that the solubilization and the degradation process of the in vitro methods are less efficient at digesting the organic matter when compared with the situation in vivo. However, De Boever et al. (1996), analyzing silages made from grasses, obtained OMD values with cellulases which were 3.1 percentage units lower than digestibility in vivo. These authors observed that this situation prevailed in a lesser magnitude for silages of low to moderate 
Table 1. Chemical composition, gross energy (GE), dry matter digestibility (DMD) and metabolizable energy (ME) of the silages in any phenological stage (DM, except pH).

\begin{tabular}{|c|c|c|c|}
\hline \multirow[b]{2}{*}{ Silage } & \multicolumn{3}{|c|}{ Phenological stage } \\
\hline & Vegetative & Ear emergency & Dough grain \\
\hline \multicolumn{4}{|l|}{ Permanent pasture: } \\
\hline $\mathrm{DM}, \mathrm{g} \mathrm{kg}^{-1}$ & $164 \pm 1.0$ & $211 \pm 4.6$ & $300 \pm 3.0$ \\
\hline $\mathrm{CP}, \mathrm{g} \mathrm{kg}^{-1} \mathrm{DM}$ & $146 \pm 1.2$ & $112 \pm 9.0$ & $83 \pm 1.8$ \\
\hline $\mathrm{CF}, \mathrm{g} \mathrm{kg}^{-1} \mathrm{DM}$ & $325 \pm 3.0$ & $342 \pm 24.1$ & $350 \pm 14.0$ \\
\hline $\mathrm{NDF}, \mathrm{g} \mathrm{kg}^{-1} \mathrm{DM}$ & $621 \pm 3.1$ & $635 \pm 28.5$ & $670 \pm 10$ \\
\hline $\mathrm{ADF}, \mathrm{g} \mathrm{kg}^{-1} \mathrm{DM}$ & $375 \pm 1.3$ & $396 \pm 22.2$ & $424 \pm 8.1$ \\
\hline Ash, $\mathrm{g} \mathrm{kg}^{-1} \mathrm{DM}$ & $99 \pm 0.9$ & $83 \pm 2.8$ & $69 \pm 1.0$ \\
\hline $\mathrm{pH}$ & $4.82 \pm 0.05$ & $4.23 \pm 0.34$ & $4.14 \pm 0.065$ \\
\hline Ammonium $\mathrm{N}, \mathrm{g} \mathrm{kg}^{-1} \mathrm{~N}$ & $196 \pm 2.6$ & $112 \pm 9.4$ & $81 \pm 5.4$ \\
\hline GE, Mcal kg ${ }^{-1} \mathrm{DM}$ & $4.70 \pm 0.04$ & $4.57 \pm 0.06$ & $4.42 \pm 0.055$ \\
\hline $\mathrm{DMD}$ in vivo, $\mathrm{g} \mathrm{kg}^{-1}$ & $657 \pm 18.3$ & $663 \pm 11.0$ & $539 \pm 6.1$ \\
\hline $\mathrm{ME}$ in vivo, Mcal $\mathrm{kg}^{-1} \mathrm{DM}$ & $2.39 \pm 0.05$ & $2.42 \pm 0.10$ & $1.99 \pm 0.02$ \\
\hline DMD ruminal fluid, $\mathrm{g} \mathrm{kg}^{-1}$ & $719 \pm 2.7$ & $689 \pm 7.4$ & $584 \pm 11.8$ \\
\hline ME ruminal fluid, $\mathrm{Mcal} \mathrm{kg}^{-1} \mathrm{DM}$ & $2.38 \pm 0.01$ & $2.34 \pm 0.03$ & $2.03 \pm 0.05$ \\
\hline OMD ruminal fluid, $\mathrm{g} \mathrm{kg}^{-1}$ & $715 \pm 1.5$ & $690 \pm 15$ & $579 \pm 15.8$ \\
\hline \multicolumn{4}{|l|}{ Perennial ryegrass: } \\
\hline $\mathrm{DM}, \mathrm{g} \mathrm{kg}^{-1}$ & $167 \pm 3.2$ & $216 \pm 2.7$ & $272 \pm 10$ \\
\hline $\mathrm{CP}, \mathrm{g} \mathrm{kg}^{-1} \mathrm{DM}$ & $120 \pm 2.7$ & $89 \pm 1.1$ & $73 \pm 3.5$ \\
\hline $\mathrm{CF}, \mathrm{g} \mathrm{kg}^{-1} \mathrm{DM}$ & $348 \pm 11$ & $317 \pm 4.7$ & $329 \pm 1.4$ \\
\hline $\mathrm{NDF}, \mathrm{g} \mathrm{kg}^{-1} \mathrm{DM}$ & $610 \pm 27$ & $578 \pm 13$ & $628 \pm 11$ \\
\hline $\mathrm{ADF}, \mathrm{g} \mathrm{kg}^{-1} \mathrm{DM}$ & $411 \pm 12$ & $375 \pm 5.3$ & $413 \pm 3.2$ \\
\hline Ash, $\mathrm{g} \mathrm{kg}^{-1} \mathrm{DM}$ & $90 \pm 3.4$ & $88 \pm 4.0$ & $78 \pm 0.3$ \\
\hline $\mathrm{pH}$ & $4.03 \pm 0.20$ & $3.69 \pm 0.06$ & $4.06 \pm 0.12$ \\
\hline Ammonium $\mathrm{N}, \mathrm{g} \mathrm{kg}^{-1} \mathrm{~N}$ & $97 \pm 9.9$ & $85 \pm 6.5$ & $59 \pm 4.1$ \\
\hline GE, Mcal kg-1 MS & $4.47 \pm 0.06$ & $4.55 \pm 0.04$ & $4.33 \pm 0.06$ \\
\hline $\mathrm{DMD}$ in vivo, $\mathrm{g} \mathrm{kg}^{-1}$ & $670 \pm 7.5$ & $639 \pm 15$ & $554 \pm 23$ \\
\hline $\mathrm{ME}$ in vivo, Mcal kg-1 DM & $2.55 \pm 0.03$ & $2.60 \pm 0.01$ & $2.09 \pm 0.06$ \\
\hline DMD ruminal fluid, $\mathrm{g} \mathrm{kg}^{-1}$ & $749 \pm 1.6$ & $724 \pm 2.6$ & $603 \pm 11$ \\
\hline ME ruminal fluid, $\mathrm{Mcal} \mathrm{kg}^{-1} \mathrm{DM}$ & $2.50 \pm 0.01$ & $2.43 \pm 0.00$ & $2.05 \pm 0.02$ \\
\hline OMD ruminal fluid, $\mathrm{g} \mathrm{kg}^{-1}$ & $752 \pm 00$ & $726 \pm 3.1$ & $606 \pm 11$ \\
\hline \multicolumn{4}{|l|}{ Mixed pasture: } \\
\hline $\mathrm{DM}, \mathrm{g} \mathrm{kg}^{-1}$ & $183 \pm 26.6$ & $219 \pm 1.6$ & $199 \pm 10.0$ \\
\hline $\mathrm{CP}, \mathrm{g} \mathrm{kg}^{-1} \mathrm{DM}$ & $174 \pm 5.7$ & $133 \pm 4.2$ & $106 \pm 2.5$ \\
\hline $\mathrm{CF}, \mathrm{g} \mathrm{kg}^{-1} \mathrm{DM}$ & $277 \pm 3.0$ & $302 \pm 0.64$ & $331 \pm 1.2$ \\
\hline $\mathrm{NDF}, \mathrm{g} \mathrm{kg}^{-1} \mathrm{DM}$ & $499 \pm 9.2$ & $567 \pm 13.8$ & $639 \pm 6.0$ \\
\hline $\mathrm{ADF}, \mathrm{g} \mathrm{kg}^{-1} \mathrm{DM}$ & $318 \pm 7.3$ & $367 \pm 2.6$ & $405 \pm 3.0$ \\
\hline Ash, $\mathrm{g} \mathrm{kg}^{-1} \mathrm{DM}$ & $103 \pm 0.9$ & $89.4 \pm 1.9$ & $84.1 \pm 0.8$ \\
\hline $\mathrm{pH}$ & $3.81 \pm 0.04$ & $3.84 \pm 0.05$ & $3.90 \pm 0.12$ \\
\hline Ammonium $\mathrm{N}, \mathrm{g} \mathrm{kg}^{-1} \mathrm{~N}$ & $102 \pm 0.4$ & $81.8 \pm 21.3$ & $70.5 \pm 8.5$ \\
\hline GE, Mcal kg-1 MS & $4.63 \pm 0.01$ & $4.51 \pm 0.01$ & $4.48 \pm 0.03$ \\
\hline $\mathrm{DMD}$ in vivo, $\mathrm{g} \mathrm{kg}^{-1}$ & $724 \pm 31.4$ & $688 \pm 21.5$ & $555 \pm 15.7$ \\
\hline $\mathrm{ME}$ in vivo, Mcal kg-1 DM & $2.91 \pm 0.15$ & $2.69 \pm 0.23$ & $2.11 \pm 0.10$ \\
\hline
\end{tabular}




\begin{tabular}{|c|c|c|c|}
\hline \multirow[b]{2}{*}{ Silage } & \multicolumn{3}{|c|}{ Phenological stage } \\
\hline & Vegetative & Ear emergency & Dough grain \\
\hline DMD ruminal fluid, $\mathrm{g} \mathrm{kg}^{-1}$ & $818 \pm 8.1$ & $736 \pm 41.7$ & $660 \pm 5.5$ \\
\hline ME ruminal fluid, Mcal kg-1 DM & $2.69 \pm 0.01$ & $2.47 \pm 0.12$ & $2.25 \pm 0.02$ \\
\hline OMD ruminal fluid, $\mathrm{g} \mathrm{kg}^{-1}$ & $827 \pm 4.0$ & $740 \pm 39.4$ & $660 \pm 6.3$ \\
\hline Oats: & $166 \pm 8.6$ & $191 \pm 23.4$ & $253 \pm 7.0$ \\
\hline $\mathrm{DM}, \mathrm{g} \mathrm{kg}^{-1}$ & $176 \pm 0.5$ & $113 \pm 3.9$ & $79.9 \pm 3.3$ \\
\hline $\mathrm{CP}, \mathrm{g} \mathrm{kg}^{-1} \mathrm{DM}$ & $309 \pm 6.3$ & $348 \pm 9.1$ & $335 \pm 0.2$ \\
\hline $\mathrm{CF}, \mathrm{g} \mathrm{kg}^{-1} \mathrm{DM}$ & $533 \pm 8.3$ & $606 \pm 9.5$ & $650 \pm 6.5$ \\
\hline $\mathrm{NDF}, \mathrm{g} \mathrm{kg}^{-1} \mathrm{DM}$ & $365 \pm 6.2$ & $411 \pm 14.1$ & $409 \pm 7.3$ \\
\hline $\mathrm{ADF}, \mathrm{g} \mathrm{kg}^{-1} \mathrm{DM}$ & $125 \pm 18.0$ & $89 \pm 3.6$ & $68 \pm 5.4$ \\
\hline Ash, $\mathrm{g} \mathrm{kg}^{-1} \mathrm{DM}$ & $4.29 \pm 0.21$ & $3.97 \pm 0.05$ & $3.96 \pm 0.02$ \\
\hline $\mathrm{pH}$ & $132 \pm 26.0$ & $110 \pm 12.2$ & $104 \pm 10.8$ \\
\hline Ammonium $\mathrm{N}, \mathrm{g} \mathrm{kg}^{-1} \mathrm{~N}$ & $4.52 \pm 0.08$ & $4.46 \pm 0.02$ & $4.46 \pm 0.03$ \\
\hline GE, Mcal kg-1 MS & $717 \pm 18.2$ & $702 \pm 31.7$ & $559 \pm 6.6$ \\
\hline DMD in vivo, $\mathrm{g} \mathrm{kg}^{-1}$ & $2.97 \pm 0.05$ & $2.74 \pm 0.22$ & $2.10 \pm 0.07$ \\
\hline $\mathrm{ME}$ in vivo, $\mathrm{Mcal} \mathrm{kg}^{-1} \mathrm{DM}$ & $800 \pm 14.6$ & $759 \pm 10.1$ & $565 \pm 21.5$ \\
\hline DMD ruminal fluid, $\mathrm{g} \mathrm{kg}^{-1}$ & $2.60 \pm 0.07$ & $2.53 \pm 0.06$ & $1.97 \pm 0.06$ \\
\hline ME ruminal fluid, Mcal kg-1 DM & $806 \pm 17.2$ & $707 \pm 35.1$ & $558 \pm 24.1$ \\
\hline OMD ruminal fluid, $\mathrm{g} \mathrm{kg}^{-1}$ & & & \\
\hline
\end{tabular}

CP: crude protein; CF: crude fibre; NDF: neutral detergent fibre; ADF: acid detergent fibre; GE: gross energy; DMD: dry matter digestibility; ME: metabolizable energy; OMD: organic matter digestibility.

Table 2. Regression equations, adjusted coefficients of determination and estimation error between in vivo $\mathrm{D}$ value (y) and $D$ value obtained with cellulase $(x)$ in the different treatments.

\begin{tabular}{|c|c|c|c|c|c|c|}
\hline Treatments & Equation & $\mathbf{R}^{2}$ & $\begin{array}{c}\text { RMS } \\
\text { residual }\end{array}$ & $\mathrm{CV}$ & F value & $\mathbf{P}>\mathbf{F}$ \\
\hline $24 \mathrm{~h}$, water, $0.75 \mathrm{~g} \mathrm{~L}^{-1}$ & $y=1.34 x+12.43$ & 0.7491 & 4.58 & 7.04 & 45.78 & $* * *$ \\
\hline $24 \mathrm{~h}$, water, $1.0 \mathrm{~g} \mathrm{~L}^{-1}$ & $y=1.26 x+13.99$ & 0.6230 & 5.61 & 8.63 & 25.79 & $* * *$ \\
\hline $24 \mathrm{~h}$, water, $6.25 \mathrm{~g} \mathrm{~L}^{-1}$ & $y=1.18 x+12.62$ & 0.7815 & 4.27 & 6.57 & 54.64 & $* * *$ \\
\hline $24 \mathrm{~h}$, acetone, $0.75 \mathrm{~g} \mathrm{~L}^{-1}$ & $y=1.23 x+14.97$ & 0.7527 & 4.55 & 6.99 & 46.66 & $* * *$ \\
\hline $24 \mathrm{~h}$, acetone, $1.0 \mathrm{~g} \mathrm{~L}^{-1}$ & $y=1.20 x+14.49$ & 0.5950 & 5.82 & 8.94 & 23.04 & $* * *$ \\
\hline $24 \mathrm{~h}$, acetone, $6.25 \mathrm{~g} \mathrm{~L}^{-1}$ & $y=1.14 x+13.44$ & 0.7311 & 4.74 & 7.29 & 41.78 & $* * *$ \\
\hline $48 \mathrm{~h}$, water, $0.75 \mathrm{~g} \mathrm{~L}^{-1}$ & $y=1.25 x+13.80$ & 0.7048 & 4.97 & 7.64 & 36.81 & $* * *$ \\
\hline $48 \mathrm{~h}$, water, $1.0 \mathrm{~g} \mathrm{~L}^{-1}$ & $y=1.27 x+12.61$ & 0.7227 & 4.81 & 7.40 & 40.10 & $* * *$ \\
\hline $48 \mathrm{~h}$, water, $6.25 \mathrm{~g} \mathrm{~L}^{-1}$ & $y=1.19 x+10.51$ & 0.7215 & 4.82 & 7.42 & 39.86 & $* * *$ \\
\hline $48 \mathrm{~h}$, acetone, $0.75 \mathrm{~g} \mathrm{~L}^{-1}$ & $y=1.30 x+10.07$ & 0.7349 & 4.71 & 7.24 & 42.58 & $* * *$ \\
\hline $48 \mathrm{~h}$, acetone, $1.0 \mathrm{~g} \mathrm{~L}^{-1}$ & $y=1.30 x+9.23$ & 0.7504 & 4.57 & 7.02 & 46.10 & $* * *$ \\
\hline $48 \mathrm{~h}$, acetone, $6.25 \mathrm{~g} \mathrm{~L}^{-1}$ & $y=1.21 x+8.13$ & 0.7236 & 4.81 & 7.39 & 40.28 & $* * *$ \\
\hline
\end{tabular}

$\mathrm{R}^{2}$ : adjusted coefficient of determination; RMS residual: root mean square residual; $\mathrm{CV}$ : coefficient of variation. ***P $<0.001$. 
Table 3. Regression equations, adjusted coefficient of determination and estimation error between dry matter digestibility determined in vivo $(y)$ and dry matter digestibility determined with cellulase $(x)$ in the different treatments.

\begin{tabular}{|c|c|c|c|c|c|c|}
\hline Treatments & Equation & $\mathbf{R}^{2}$ & $\begin{array}{c}\text { RMS } \\
\text { residual }\end{array}$ & CV & F value & $P>F$ \\
\hline $24 \mathrm{~h}$, water, $0.75 \mathrm{~g} \mathrm{~L}^{-1}$ & $y=0.78 x+27.39$ & 0.6475 & 3.74 & 5.93 & 28.55 & $* * *$ \\
\hline $24 \mathrm{~h}$, water, $1.0 \mathrm{~g} \mathrm{~L}^{-1}$ & $y=0.72 x+29.20$ & 0.5368 & 4.28 & 6.80 & 18.38 & $* * *$ \\
\hline $24 \mathrm{~h}$, water, $6.25 \mathrm{~g} \mathrm{~L}^{-1}$ & $y=0.71 x+26.75$ & 0.7110 & 3.38 & 5.37 & 37.91 & $* * *$ \\
\hline $24 \mathrm{~h}$, acetone, $0.75 \mathrm{~g} \mathrm{~L}^{-1}$ & $y=0.74 x+27.95$ & 0.6606 & 3.67 & 5.82 & 30.19 & $* * *$ \\
\hline $24 \mathrm{~h}$, acetone, $1.0 \mathrm{~g} \mathrm{~L}^{-1}$ & $y=0.61 x+33.74$ & 0.4802 & 4.54 & 7.20 & 14.86 & $* * *$ \\
\hline $24 \mathrm{~h}$, acetone, $6.25 \mathrm{~g} \mathrm{~L}^{-1}$ & $y=0.69 x+27.24$ & 0.6791 & 3.57 & 5.66 & 32.75 & $* * *$ \\
\hline $48 \mathrm{~h}$, water, $0.75 \mathrm{~g} \mathrm{~L}^{-1}$ & $y=0.73 x+28.58$ & 0.5993 & 3.98 & 6.32 & 23.44 & $* * *$ \\
\hline $48 \mathrm{~h}$, water, $1.0 \mathrm{~g} \mathrm{~L}^{-1}$ & $y=0.74 x+27.75$ & 0.6372 & 3.79 & 6.02 & 27.34 & $* * *$ \\
\hline $48 \mathrm{~h}$, water, $6.25 \mathrm{~g} \mathrm{~L}^{-1}$ & $y=0.76 x+24.27$ & 0.6915 & 3.50 & 5.55 & 34.62 & $* * *$ \\
\hline $48 \mathrm{~h}$, acetone, $0.75 \mathrm{~g} \mathrm{~L}^{-1}$ & $y=0.77 x+25.48$ & 0.6688 & 3.62 & 5.75 & 31.28 & $* * *$ \\
\hline $48 \mathrm{~h}$, acetone, $1.0 \mathrm{~g} \mathrm{~L}^{-1}$ & $y=0.75 x+25.98$ & 0.6671 & 3.63 & 5.76 & 31.06 & $* * *$ \\
\hline $48 \mathrm{~h}$, acetone, $6.25 \mathrm{~g} \mathrm{~L}^{-1}$ & $y=0.69 x+26.03$ & 0.6610 & 3.67 & 5.81 & 30.25 & $* * *$ \\
\hline
\end{tabular}

$\mathrm{R}^{2}$ : adjusted coefficient of determination; RMS residual: root mean square residual; CV: coefficient of variation. $* * * \mathrm{P}<0.001$.

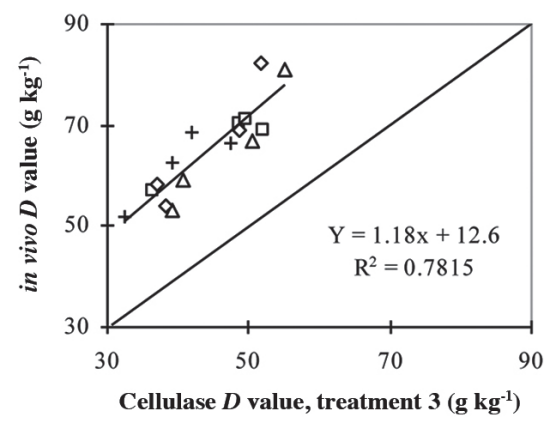

Figure 1. Relationship between D value obtained in vivo and with cellulase, according to the best enzymatic treatment (Treatment 3). Symbols represent silages made from permanent pasture $(+)$, perennial ryegrass $(\mathfrak{E})$, mixed pasture $(\Delta)$, or oats $(\diamond)$. digestibility, but greater magnitude for those with high digestibility. Huhtanen et al. (2006) suggested that the ratio between OMD with cellulases and OMD in vivo is not uniform between different forages. In their study they found that by using specific equations for each forage, the prediction error can be reduced, as compared with a general equation.

Table 4 presents the correlation matrix for determinations of DMD with rumen fluid, DMD with cellulase, DMD in vivo, D value by the same techniques and organic matter digestibility (OMD) by rumen fluid and cellulases. As expected, the highest relationships ( $\mathrm{r}>$ $0.9)$ were found between digestibility (DM and OM) and the corresponding $\mathrm{D}$ value for each in vitro, as for the in vivo, technique as well. Apart from that, it is noteworthy the significant correlation ( $\mathrm{ca} .0 .87)$ found between the

Table 4. Correlation between determinations of dry matter digestibility, D value, and digestibility of organic matter obtained in vivo, with rumen liquor and with cellulase.

\begin{tabular}{lcccccccc}
\hline & DMD rl & DMD cel & $\begin{array}{c}\text { DMD } \\
\text { in vivo }\end{array}$ & D value rl & D value cel & $\begin{array}{c}\text { D value } \\
\text { in vivo }\end{array}$ & OMD rl & OMD cel \\
\hline DMD rl & 1.00 & $0.9092^{*}$ & $0.8617^{*}$ & $0.9976^{*}$ & $0.8824^{*}$ & $0.8663^{*}$ & $0.9395^{*}$ & $0.8926^{*}$ \\
DMD cel & - & 1.00 & $0.8286^{*}$ & $0.9033^{*}$ & $0.9940^{*}$ & $0.8705^{*}$ & $0.8520^{*}$ & $0.9971^{*}$ \\
DMD in vivo & - & - & 1.00 & $0.8674^{*}$ & $0.8046^{*}$ & $0.9285^{*}$ & $0.7522^{*}$ & $0.8114^{*}$ \\
D value rl & - & - & - & 1.00 & $0.8788^{*}$ & $0.8789^{*}$ & $0.9284^{*}$ & $0.8878^{*}$ \\
D value cel & - & - & - & - & 1.00 & $0.8688^{*}$ & $0.8169^{*}$ & $0.9991^{*}$ \\
D value in vivo & - & - & - & - & - & 1.00 & $0.7356^{*}$ & $0.8684^{*}$ \\
OMD rl & - & - & - & - & - & - & 1.00 & $0.8296^{*}$ \\
OMD cel & - & - & - & - & - & - & - & 1.00 \\
\hline
\end{tabular}

DMD rl: dry matter digestibility determined with ruminal fluid; DMD cel: dry matter digestibility determined with cellulases; DMD in vivo: dry matter digestibility determined in vivo; D value rl: organic matter digestibility determined with ruminal fluid; D value cel: organic matter digestibility determined with cellulases; D value in vivo: organic matter digestibility determined in vivo; OMD rl: organic matter digestibility determined with ruminal fluid; OMD cel: organic matter digestibility determined with cellulases; OMD in vivo: organic matter digestibility determined in vivo. *p $<0.05$. 
enzymatic results (DMD, OMD and D value) with the in vivo $\mathrm{D}$ value, an important predictor of energy values. These results are comparable to those obtained with rumen fluid.

\section{Use of multiple equations for the prediction of in vivo DMD and D value}

In order to improve prediction of in vivo values from in vitro determinations, a second independent variable $(\mathrm{CF}$, GE, NDF or TA) was included in addition to the single predictors showed above. Multiple regression results (Table 5) ordered from the respective lowest to highest estimation error, show a predominance of equations involving cellulase treatments with the highest enzyme concentration (6.25 $\left.\mathrm{g} \mathrm{L} \mathrm{L}^{-1}\right)$. Furthermore, the best treatments are those with an incubation time of $24 \mathrm{~h}$. The most common predictors for the best equations (with lowest estimation error) are DMD cellulase and $\mathrm{D}$ value cellulase, both with Treatment 3, plus the content of $\mathrm{CF}, \mathrm{GE}, \mathrm{NDF}$ or TA. The independent variables in the best equation are DMD Treatment 3 and $\mathrm{CF}$, explaining almost 0.75 of the variation in DMD in vivo. When the results of the multiple equations are compared with in vivo DMD prediction through simple equations (Table 3 ), the individual use of Treatment 3 is the best predictor.

Table 5. Predicting in vivo dry matter digestibility $(\mathrm{Y})$ through multiple equations with biological and chemical parameters.

\begin{tabular}{lccc}
\hline $\mathbf{x}_{\mathbf{1}}$ & $\mathbf{x}_{\mathbf{2}}$ & $\mathbf{R}^{\mathbf{2}}$ & $\begin{array}{c}\text { RMS } \\
\text { residual }\end{array}$ \\
\hline DMD cellulase t3 & CF & 0.7442 & 3.42 \\
DMD cellulase t3 & GE & 0.7366 & 3.47 \\
DMD cellulase t3 & NDF & 0.7339 & 3.49 \\
D value cellulase t3 & CF & 0.7327 & 3.50 \\
DMD cellulase t3 & Ash & 0.7315 & 3.50 \\
DMD cellulase t3 & ADF & 0.7303 & 3.51 \\
D value cellulase t3 & GE & 0.7213 & 3.57 \\
D value cellulase t3 & NDF & 0.7176 & 3.59 \\
DMD cellulase t6 & CF & 0.7172 & 3.60 \\
DMD cellulase t9 & CF & 0.7165 & 3.60 \\
DMD cellulase t9 & NDF & 0.7149 & 3.61 \\
DMD cellulase t9 & ADF & 0.7147 & 3.62 \\
D value cellulase t3 & Ash & 0.7119 & 3.63 \\
D value cellulase t3 & ADF & 0.7110 & 3.65 \\
DMD cellulase t10 & GE & 0.7037 & 3.64 \\
\hline
\end{tabular}

t3: $24 \mathrm{~h}$, water, $6.25 \mathrm{~g} \mathrm{~L}^{-1} ; \mathrm{t} 6: 24 \mathrm{~h}$, acetone, $6.25 \mathrm{~g} \mathrm{~L}^{-1} ; \mathrm{t} 9: 48 \mathrm{~h}$, water, $6.25 \mathrm{~g} \mathrm{~L}^{-1} ; \mathrm{t} 10: 48 \mathrm{~h}$, acetone, $0.75 \mathrm{~g} \mathrm{~L}^{-1}$.

$\mathrm{R}^{2}$ : adjusted coefficient of determination; RMS residual: root mean square residual; CF: crude fibre; GE: gross energy; NDF: neutral detergent fibre; ADF: acid detergent fibre.
Table 6. Prediction of $\mathrm{D}$ value in vivo (Y) through multiple equations with biological and chemical parameters.

\begin{tabular}{|c|c|c|c|}
\hline $\mathbf{x}_{1}$ & $\mathbf{x}_{2}$ & $\mathbf{R}^{2}$ & $\begin{array}{c}\text { RMS } \\
\text { residual }\end{array}$ \\
\hline $\mathrm{D}$ value cellulase $\mathrm{t} 3$ & $\mathrm{NDF}$ & 0.8093 & 4.29 \\
\hline$D$ value cellulase $\mathrm{t} 3$ & Ash & 0.8078 & 4.30 \\
\hline DMD cellulase $\mathrm{t} 3$ & Ash & 0.8065 & 4.32 \\
\hline DMD cellulase $\mathrm{t} 3$ & NDF & 0.8032 & 4.36 \\
\hline $\mathrm{D}$ value cellulase $\mathrm{t} 3$ & $\mathrm{ADF}$ & 0.7991 & 4.40 \\
\hline$D$ value cellulase $\mathrm{t} 3$ & $\mathrm{CF}$ & 0.7967 & 4.43 \\
\hline$D$ value cellulase $t 3$ & GE & 0.7967 & 4.43 \\
\hline $\mathrm{D}$ value cellulase $\mathrm{t} 11$ & $\mathrm{NDF}$ & 0.7949 & 4.45 \\
\hline $\mathrm{D}$ value cellulase $\mathrm{t} 1$ & $\mathrm{NDF}$ & 0.7925 & 4.47 \\
\hline$D$ value cellulase $t 4$ & $\mathrm{NDF}$ & 0.7924 & 4.47 \\
\hline $\mathrm{D}$ value cellulase $\mathrm{t} 11$ & $\mathrm{ADF}$ & 0.7903 & 4.50 \\
\hline D value cellulase t 10 & $\mathrm{NDF}$ & 0.7885 & 4.52 \\
\hline $\mathrm{D}$ value cellulase $\mathrm{t} 12$ & NDF & 0.7871 & 4.53 \\
\hline DMD cellulase $\mathrm{t} 3$ & $\mathrm{ADF}$ & 0.7858 & 4.54 \\
\hline DMD cellulase $\mathrm{t} 3$ & $\mathrm{CF}$ & 0.7835 & 4.57 \\
\hline
\end{tabular}

t1: $24 \mathrm{~h}$, water, $0.75 \mathrm{~g} \mathrm{~L}^{-1} ; \mathrm{t} 3: 24 \mathrm{~h}$, water, $6.25 \mathrm{~g} \mathrm{~L}^{-1} ; \mathrm{t} 4: 24 \mathrm{~h}$, acetone, $0.75 \mathrm{~g} \mathrm{~L}^{-1}$; t10: $48 \mathrm{~h}$, acetone, $0.75 \mathrm{~g} \mathrm{~L}^{-1} ; \mathrm{t} 11: 48 \mathrm{~h}$, acetone, $1.0 \mathrm{~g} \mathrm{~L}^{-1} ; \mathrm{t} 12$ : $48 \mathrm{~h}$, acetone, $6.25 \mathrm{~g} \mathrm{~L}^{-1}$.

$\mathrm{R}^{2}$ : adjusted coefficient of determination; RMS residual: root mean square residual; CF: crude fibre; GE: gross energy; NDF: neutral detergent fibre; ADF: acid detergent fibre.

Rinne et al. (2006) propose that the use of in vitro methods together with chemical components improves the OMD prediction slightly, especially if information on the NDF concentration is incorporated. This contradicts the proposal of Givens et al. (1993), who indicate that poorer equations to predict digestibility are found when cell wall components (NDF, modified ADF, hemi-cellulose) are included and that reason is not clear. They suggest however, that this might be caused by the high drying temperature $\left(100{ }^{\circ} \mathrm{C}\right)$ used prior to the analysis of the cell wall fractions. Likewise, Giger-Reverdin et al. (1994) indicate that in predicting OMD, the inclusion of the lignin content in the equations improves the OMD prediction ( $\mathrm{r}$ $=0.81$; estimation error $=2.77)$, as compared to $\mathrm{CF}(\mathrm{r}=$ 0.42 ; estimation error $=4.26$ ), cell wall or lignocellulose, when these criteria are considered separately. One possible explanation may be found in the characteristics of the material to be evaluated. Digestibility is dependent on the moment when the different grasses are cut, and therefore a different adjustment factor might be required to correct the digestibility prediction equation depending on the period when the forage was harvested. This would be due to the fact that the quantity of cellulase used would be insufficient for fibre-rich forages, but excessive for those of good quality (De Boever et al., 1996). Huhtanen et al. (2006) indicate that the relative efficiency of the enzyme systems to solubilize the $\mathrm{OM}$ from forages diminishes as 
the concentration of NDF potentially digestible by the micro-organisms in the rumen increases.

Prediction equations for $\mathrm{D}$ value in vivo through any in vitro cellulase digestibility trait, combined with one of several chemical fractions (Table 6) ordered from the respective lowest to highest estimation error, show that the best equations are those involving Treatment 3 , and that in general, equations including a fibre component such as NDF and ADF, outrank the rest. The inclusion of NDF in the equation with D value cellulase Treatment 3 , obtained the smallest error among the multiple regression equations, explaining 0.81 of the variance. Rinne et al. (2006) propose that the OMD of the forage is essentially dependent on its NDF concentration and NDF digestibility. For this reason, they affirm that any method used for predicting the forage OMD in vivo must mimic the NDF degradation by the micro-organisms in the rumen. According to Kuoppala et al. (2008) the moment of harvest (phenological stage) of the grass at the first cut has proved to be the major factor affecting digestibility and subsequent intake and milk production in dairy cows.

Different performance is observed in the enzymatic method according to the phenological stage in which the forage is harvested. It is thought that the concentration of cellulase used presents a different degree of efficiency depending on the maturity of the forage, which affects the dispersion of results and their adjustment in different sectors of the fitted regression line. This was also observed by Givens et al. (1993) and De Boever et al. (1994). However, these results contradict those presented by Givens et al. (1990), who suggest that in vitro methods based on cellulases are relatively stable between years and types of forage. Van Soest et al. (1978) proposed that the interactions between regions and forage species may increase errors in predicting digestibility. For this reason, to improve the certainty in predicting in vivo digestibility, it seems advisable to develop a different equation for each type of silage and/or for extreme phenological stages.

\section{CONCLUSIONS}

The best predictions (simple linear regressions) of in vivo $D$ value and DMD were obtained with the highest cellulase concentration $\left(6.25 \mathrm{~g} \mathrm{~L}^{-1}\right), 24 \mathrm{~h}$ of incubation, and water in the final wash. When a second independent variable (one of several chemical fractions) was included (multiple regression) the best prediction of in vivo DMD and D value, also involved cellulase treatment with the highest enzyme concentration (specially Treatment 3 ) and the use of crude fibre, gross energy, neutral detergent fibre or total ash. The results obtained with the use of cellulases in determining digestibility are lower than those obtained in vivo, and closer to those obtained with ruminal fluid. This lack of accuracy with respect to the in vivo values is to be expected, and may be explained by the lower capacity of one type of enzyme in particular to degrade a set of cell wall components which represent a greater complexity from the chemical point of view. This situation could be corrected and equations improved (reducing estimation error and increasing percentage of explained variance) through the application of correction factors which allow the estimated values to be brought closer to those observed in vivo. The justification for using a factor of a general type, or a different one for each type of forage evaluated (botanical composition, phenological stage, type of conservation, etc.) should be a subject for further studies.

\section{RESUMEN}

Uso de celulasas para predecir el contenido de materia orgánica digestible (Valor D) in vivo, en ensilajes de praderas. En sistemas lecheros pastoriles que utilizan ensilaje como suplemento, se requiere conocer el valor nutricional de éste para optimizar la alimentación del ganado. La energía metabolizable, importante fracción nutricional, puede estimarse a partir de la materia orgánica digestible contenida en la materia seca (Valor-D). El objetivo de este trabajo fue evaluar la predicción del valor-D y la digestibilidad de la materia seca (DMS) de ensilajes de pradera, usando el método de pepsinacelulasa. Se utilizó celulasa fúngica con diferentes concentraciones, tiempos de incubación y tipo de lavado final. Los ensilajes estudiados fueron preparados a partir de pradera permanente (Dactylis glomerata L., Lolium perenne L., Bromus catharticus Vahl var. catharticus, Trifolium repens L. y Holcus lanatus L.), pradera de rotación (L. multiflorum Lam. cv. Tama), avena (Avena sativa L.), y pradera mixta (L. perenne-T. repens); cosechadas en tres estados fenológicos. El tratamiento con un tiempo de incubación de 24 h, concentración de celulasa de 6,25 $\mathrm{g} \mathrm{L}^{-1}$ y lavado con agua (Tratamiento 3) presentó la mejor capacidad de predicción del valor $\mathrm{D}$ in vivo $\left(\mathrm{R}^{2}=0,78\right)$ y de la digestibilidad de la materia seca (DMS) in vivo $\left(\mathrm{R}^{2}=0,71\right)$. La predicción del valor $\mathrm{D}$ in vivo mejoró levemente $\left(\mathrm{R}^{2}=0,8\right)$ al incluir una determinación química (fibra cruda, energía bruta, fibra detergente neutro, cenizas o fibra detergente ácido) junto al valor D obtenido con el Tratamiento 3 de celulasas (regresión múltiple). Los resultados obtenidos con el uso de celulasas para determinar la digestibilidad subestiman a los obtenidos in vivo, siendo más cercanos a los obtenidos con fluido ruminal. El uso de ecuaciones adecuadas podría mejorar la exactitud de las predicciones.

Palabras clave: ensilaje de pradera, in vitro, digestibilidad de la materia seca, Trichoderma viride. 


\section{LITERATURE CITED}

Alomar, D., y R. Fuchslocher. 1998. Fundamentos de la espectroscopía de reflectancia en el infrarrojo cercano (NIRS) como método de análisis de forrajes. Agro Sur 26:88-104.

AOAC. 1996. Official methods of analysis. 15th ed. Association of Official Analytical Chemists, Washington, D.C., USA.

Bateman, J.V. 1970. Nutrición animal: Manual de métodos analíticos. 468 p. Centro Regional de Ayuda Técnica, México D.F.

Cody, R., and J. Smith. 1991. Applied statistics and the SAS programming language. $3^{\text {rd }}$ ed. 403 p. Elsevier Science Publishing Amsterdam, The Netherlands.

De Boever, J., B. Cottyn, D.L. De Brabander, J.M. Vanacker, and Ch. Boucque. 1996. Prediction of the feeding value of grass silages by chemical parameters, in vitro digestibility and near-infrared reflectance spectroscopy. Animal Feed Science and Technology 60:103-115.

De Boever, J., B. Cottyn, J.M. Vanacker, and Ch. Boucqué. 1994. An improved enzymatic method by adding gammanase to determine digestibility and predict energy value of compound feeds and raw materials for cattle. Animal Feed Science and Technology 47:1-18.

Di Marco, O.N., M.A. Ressia, S. Arias, M.S. Aello, and M. Arzadún. 2009. Digestibility of forage silages from grain, sweet and bmr sorghum types: Comparison of in vivo, in situ and in vitro data. Animal Feed Science and Technology 153:161-168.

Dowman, M., and F. Collins. 1982. The use of enzymes to predict the digestibility of animal feeds. Journal of the Science of Food and Agriculture 33:689-696.

Garrido, O., y E. Mann. 1981. Composición química, digestibilidad y valor energético de una pradera permanente de pastoreo a través del año. Tesis Ingeniero Agrónomo. Universidad Austral de Chile, Valdivia, Chile.

Giger-Reverdin, S., J. Aufrère, D. Sauvant, C. Demarquilly, and M. Vermorel. 1994. Prediction of the energy values of compound feeds for ruminant. Animal Feed Science and Technology 48:73-98.

Givens, D., J. Everington, and A. Adamson. 1990. The nutritive value of spring-grown herbage produced on farms throughout England and Wales over 4 years. II. The prediction of apparent digestibility in vivo from various laboratory measurements. Animal Feed Science and Technology 27:173-184.

Givens, D., A. Moss, and A. Adamson. 1993. Influence of growth stage and season on the energy value of fresh herbage. 2. Relationships between digestibility and metabolizable energy content and various laboratory measurements. Grass and Forage Science 48:175-180.
Huhtanen, P., J. Nousiainen, and M. Rinne. 2005. Prediction of composition and organic matter digestibility from herbage composition and pepsin-cellulase solubility. Agricultural and Food Science 14:154-165.

Huhtanen, P., J. Nousiainen, and M. Rinne. 2006. Recent developments in forage evaluation with special reference to practical applications. Agricultural and Food Science 15:293-323.

Ibáñez, L., and D. Alomar. 2008. Prediction of the chemical composition and fermentation parameters of pasture silage by near infrared reflectance spectroscopy (NIRS). Chilean Journal of Agricultural Research 68:352-359.

Jones, D., and M. Hayward. 1975. The effect of pepsin pretreatment of herbage on the prediction of dry matter digestibility from solubility in fungal cellulase solutions. Journal of the Science of Food and Agriculture 26:711-718.

Jones, D., and M. Theodorou. 2000. Enzyme techniques for estimating digestibility. p. 155-173. In Givens, D., E. Owen, R. Axford, and H. Omed (eds.) Forage evaluation in ruminant nutrition. CABI Publishing, Oxon, UK.

Kuoppala, K., M. Rinne, J. Nousiainen, and P. Huhtanen. 2008. The effect of cutting time of grass silage in primary growth and regrowth and the interactions between silage quality and concentrate level on milk production of dairy cows. Livestock Science 116:171-182.

Nousiainen, J., M. Rinne, M. Hellämäki, and P. Huhtanen. 2003. Prediction of the digestibility of the primary growth of grass silages harvested at different stages of maturity from chemical composition and pepsin-cellulase solubility. Animal Feed Science and Technology 103:97-111.

Rinne, M., A. Olt, J. Nousiainen, A. Seppa, M. Tuori, C. Paul, M. Fraser, and P. Huhtanen. 2006. Prediction of legume silage digestibility from various laboratory methods. Grass and Forage Science 61:354-362.

Robinson, P.H., Givens, D.I., and G. Getachew. 2004. Evaluation of NRC, UC Davis and ADAS approaches to estimate the metabolizable energy values of feeds at maintenance energy intake from equations utilizing chemical assays and in vitro determinations. Animal Feed Science and Technology 114:75-90.

SAS Institute. 2009. JMP 8 Design of experiments. SAS Institute, Cary, North Carolina, USA.

Steel, R., y J. Torrie. 1988. Bioestadística: principios y procedimientos. 622 p. $2^{\text {a }}$ ed. McGraw-Hill, México.

Tilley, J., and R. Terry. 1963. A two stage technique for the in vitro digestion of forage crops. Grass and Forage Science 18:104-111.

Van Soest, P.J., D.R. Mertens, and B. Deinum. 1978. Preharvest factors influencing quality of conserved forage. Journal of Animal Science 47:712-720. 